\title{
PENGARUH VARIASI SUHU PRE-GELATINISASI TERHADAP SIFAT FISIK, KIMIA DAN FISIKOKIMIA TEPUNG BENGKUANG YANG DIMODIFIKASI
}

\author{
THE EFFECT OF VARIOUS OF TEMPERATURE ON PHYSICAL, CHEMICHAL AND \\ PHYSICOCHEMICAL PROPERTIES OF YAM BEAN PRE-GELATINIZED FLOUR)
}

\author{
Achmad Ridwan Ariyantoro ${ }^{1}$, Nur Her Riyadi Parnanto ${ }^{1}$, Endah Dwi Kuntatiek ${ }^{2}$ \\ 1) Staf Pengajar di Program Studi Ilmu Teknologi Pangan, Universitas Sebelas Maret, Surakarta \\ 2) Alumni Program Studi Ilmu Teknologi Pangan, Universitas, Sebelas Maret, Surakarta \\ Email : ridwan030586@ gmail.com
}

Diserahkan [20 Februari 2020]; Diterima [5 Juni 2020]; Dipublikasi [22 Juni 2020]

\begin{abstract}
The purpose of this research was to investigate the effects of temperature variation $(80,90,100$ and 110 ${ }^{\circ} \mathrm{C}$ ) in the pre-gelatinization methods on physical (whiteness), chemical (moisture content) and physicochemical properties (water absorbtion capacity, solubility, and swelling power) of yam bean modified flour. This research used Completely Randomized Design (CRD) with variation of temperature variable. It was performed with three replicates of samples. The results showed that the higher temperature lead to decrease whiteness degree but increased moisture content, water absorbtion and sollubility. However, more higher temperature has no significance difference in swelling power value. The results are very important to develop food product, which are require high solubility value in water.
\end{abstract}

Keywords : Pre-gelatinization, Yam Bean Flour, Physicochemical properties

\section{ABSTRAK}

Tujuan dari penelitian ini adalah untuk mengetahui pengaruh variasi suhu $\left(80,90,100\right.$ dan $\left.110{ }^{\circ} \mathrm{C}\right)$ pada metode pre-gelatinisasi terhadap sifat fisik (derajat putih), sifat kimia (kadar air) dan sifat fisikokimia (daya serap air, kelarutan, dan swelling power) tepung bengkuang termodifikasi. Metode penelitian menggunakan Rancangan Acak Lengkap (RAL) dengan satu faktor yaitu variasi suhu dengan tiap perlakuan dilakukan sebanyak 3 (tiga) kali perulangan sampel dengan 2 kali analisis. Hasil uji sifat fisik (derajat putih) tepung pregelatinisasi menunjukkan semakin tinggi suhu pre-gelatinisasi, maka nilai derajat putih tepung bengkuang pregelatinisasi semakin menurun. Sifat kimia (kadar air) pada tepung bengkuang pre-gelatinisasi menunjukkan semakin tinggi suhu pre-gelatinisasi, maka nilai kadar air tepung bengkuang pre-gelatinisasi semakin meningkat. Sifat fisikokimia tepung pre-gelatinisasi menunjukkan semakin tinggi suhu pre-gelatinisasi maka nilai daya serap air dan kelarutan (sollubility) juga semakin meningkat. Sedangkan, kenaikan suhu pre-gelatinisasi tidak menyebabkan perubahan secara signifikan pada nilai swelling power. Hasil tepung modifikasi ini dapat digunakan untuk pengembangan produk pangan yang membutuhkan nilai kelarutan yang tinggi.

Kata Kunci : Pre-gelatinisasi, Tepung Bengkuang, Sifat Fisikokimia.

\section{PENDAHULUAN}

Salah satu bahan pangan yang terus meningkat permintaannya yaitu tepung. Bahan pangan lokal yang dapat dikembangkan menjadi tepung adalah umbiumbian, di mana umbi mengandung banyak karbohidrat yang bermanfaat. Salah satu umbi-umbian yang dapat dimanfaatkan sebagai sumber karbohidrat dalam pembuatan tepung adalah umbi bengkuang. Umbi bengkuang merupakan tananam yang biasa tumbuh di dataran rendah. Daerah yang membudidayakan umbi bengkuang ini di Propinsi Jawa Tengah adalah salah satunya Kabupaten Kebumen. Menurut data BPS Kebumen (2005-2007) ada empat kecamatan sentra produksi bengkuang yang total produksinya berkisar 5,020-7,030 ton/tahun. Pemanfaatan umbi bengkuang menjadi produk olahan masih sangat sederhana, sedangkan hasil produksi umbi bengkuang sendiri sangat melimpah. Sehingga perlu dilakukan sebuah usaha untuk pemanfaatan umbi bengkuang yang lebih luas.

Penyimpanan bengkuang yang terlalu lama menyebabkan umbinya berserat, oleh karena itu diperlukan upaya untuk mengawetkan bengkuang dalam bentuk tepung. Bengkuang dapat dimanfaatkan dalam beberapa bentuk makanan jadi atau setengah jadi (intermediate product). Salah satu pengolahan bengkuang menjadi produk setengah jadi yaitu berupa tepung. 
Kandungan kimia bengkuang memiliki komposisi yang bervariasi sesuai dengan jenis kultivar dan kematangan bagian tanamannya. Pada bentuk umbi siap panen, bengkuang mengandung $80-90 \%$ air, $10-$ $17 \%$ karbohidrat, $1-2,5 \%$ protein, $0,5-1 \%$ serat, $0,1-0,2 \%$ lemak dan vitamin C. Pada buah muda bengkuang mengandung $86 \%$ air, $10 \%$ karbohidrat, $2,6 \%$ protein, $0,9 \%$ serat, 0,3\% lemak dan vitamin C (Chooi, 2003).

Salah satu kelemahan tepung bengkuang yaitu jika dimasak membutuhkan waktu yang lama karena tidak mudah larut dalam air. Oleh karena itu, upaya perbaikan kualitas tepung bengkuang penting untuk dilakukan, antara lain dengan modifikasi sifat fisikokimia menggunakan metode pregelatinisasi. Pre-gelatinisai dipilih karena dapat meningkatkan kelarutan dari tepung bengkuang. Sehingga, penelitian ini penting dilakukan untuk mengetahui pengaruh perbedaan suhu pre-gelatinisasi terhadap sifat fisik, kimia dan fisikokimia tepung yang dimodifikasi.

\section{METODE PENELITIAN}

\section{Bahan}

Bahan yang digunakan dalam pembuatan tepung modifikasi adalah umbi bengkuang yang diperoleh dari Pasar Gede Surakarta. Adapun bahan yang digunakan untuk analisis tepung modifikasi yaitu tepung bengkuang dan aquadest. Semua bahan digunakan menurut ukuran masing-masing analisis yang dibutuhkan.

\section{Alat}

Alat-alat yang digunakan dalam pembuatan tepung bengkuang adalah pisau, baskom, slicer, cabinet dryer, blender, oven, ayakan 80 mesh, dan timbangan digital. Untuk alat yang digunakan dalam proses pregelatinisasi yaitu waterbath, oven, ayakan 80 mesh, loyang dan timbangan digital. Selain itu, adapula alat yang digunakan untuk analisa antara lain Analisis derajat putih (whiteness meter model C-100), analisa kadar air (botol timbang, oven, desikator, timbangan analitik, penjepit), analisa daya serap air (waterbath, oven, corong, beker glass, pengaduk, erlenmeyer dan kertas saring), analisa swelling power (waterbath, centrifuge, tabung centrifuge, spatula dan timbangan analitik), analisa solubility (kelarutan) (waterbath, oven, corong, beker glass, pengaduk, erlenmeyer dan kertas saring).

\section{Tahapan Penelitian}

\section{Pembuatan Tepung Bengkuang}

Tahapan dalam pembuatan tepung bengkuang melewati beberapa proses (Gambar 1) yaitu pencucian tahap awal. Proses ini merupakan tahap awal pada pembuatan tepung, bengkuang yang akan digunakan masih meninggalkan kotoran berupa pasir, tanah, ranting dan kotoran lainnya. Setelah itu proses pengupasan dilakukan secara manual menggunakan pisau, pengupasan harus dilakukan dengan sempurna dan hati-hati agar daging bengkuang tidak banyak terbuang.

Setelah pengupasan selesai bengkuang dicuci kembali karena saat pengupasan bengkuang menjadi kotor lagi. Bengkuang yang telah benar-benar bersih kemudian dilakukan pengecilan ukuran. Untuk kriteria dalam pengecilan ukuran dilakukan secara seragam yaitu $\pm 1 \mathrm{~mm}$ menggunakan slicer. Hal ini dilakukan karena untuk memudahkan saat proses pengeringan sehingga air yang terdapat pada bengkuang dapat keluar dengan cepat. Umbi bengkuang yang telah dikecilkan ukurannya kemudian direndam air panas dengan suhu $90^{\circ} \mathrm{C}$ selama \pm 1 menit. Blanching bertujuan untuk mencegah terjadinya pencoklatan (browning) pada umbi bengkuang. Pengeringan dilakukan menggunakan alat berupa cabinet dryer. Waktu yang digunakan saat proses pengeringan yaitu selama \pm 16 jam dengan suhu $60^{\circ} \mathrm{C}$.

Chip bengkuang yang telah kering kemudian digiling menggunakan alat penggiling tepung. Hasil penggilingan tepung bengkuang kemudian dihaluskan lagi karena bentuk tepung bengkuang yang telah digiling masih berupa butiran kasar. Proses penghalusan dilakukan menggunakan blender selama \pm 15 menit. Hal ini dilakukan untuk mendapatkan bentuk tepung yang diinginkan menjadi halus. Ukuran mesh yang digunakan yaitu 80 mesh. 


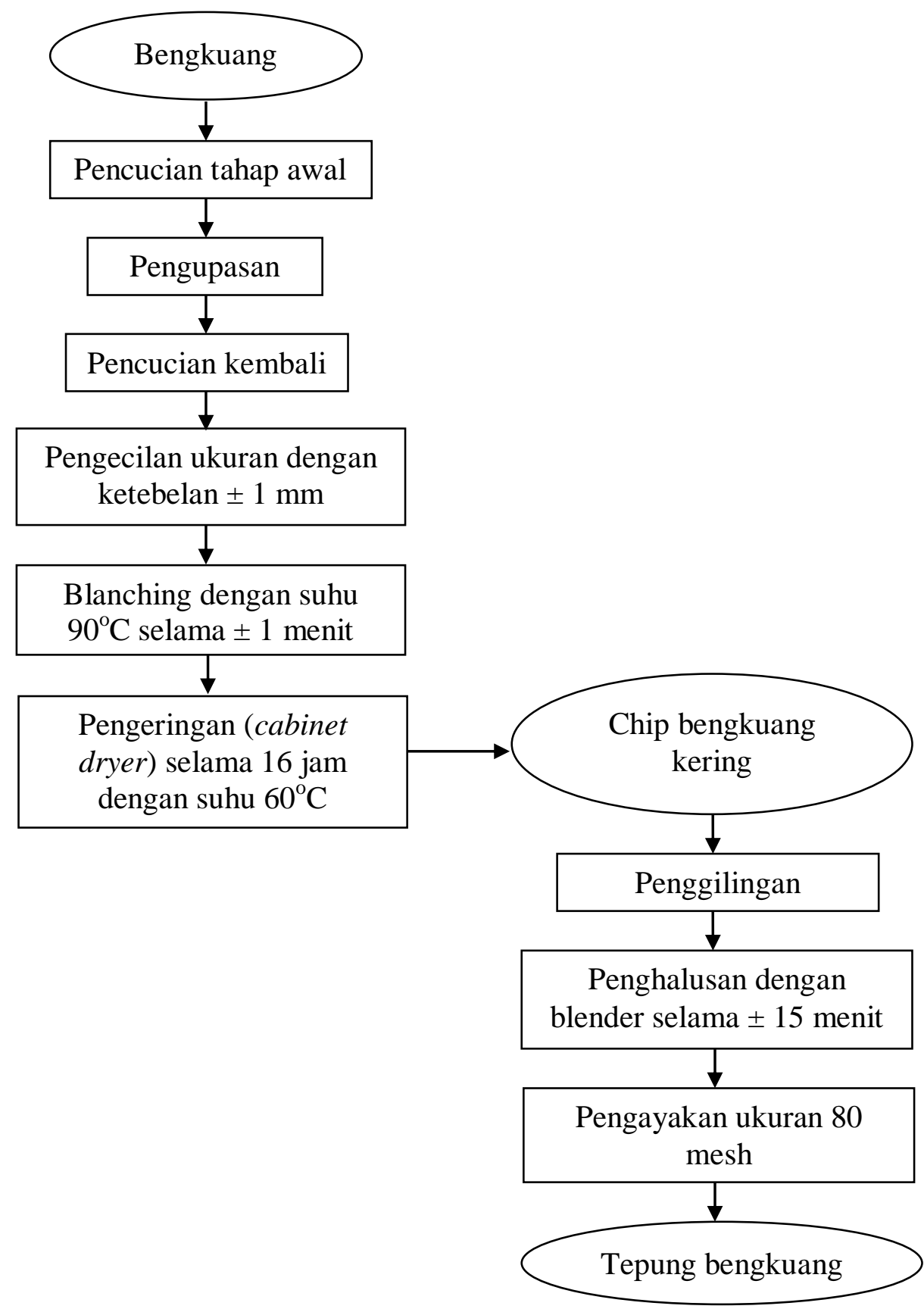

Gambar 1. Diagram Alir Pembuatan Tepung Bengkuang 


\section{Pre-gelatinisasi Tepung Bengkuang}

Tepung bengkuang yang telah dihasilkan kemudian dilakukan proses pembutan tepung modifikasi. Adapun tahapan dalam pembuatan tepung modifikasi

(Gambar 2) yaitu Tepung bengkuang yang dihasilkan diambil secukupnya. Kemudian ditambahkan aquades sebanyak $20 \%$ w/v. Setelah itu sampel yang sudah ditambah aquadest dipanaskan menggunakan waterbath. Suhu yang digunakan yaitu dipanaskan pada suhu $80,90,100$ dan $110^{\circ} \mathrm{C}$ selama 10 menit. Suhu yang digunakan diatas suhu gelatinisasi pati umbi-umbian.

Sampel yang telah dipanaskan didiamkan terlebih dahulu pada suhu ruang selama 20 menit. Setelah itu dimasukkan ke dalam freezer dengan suhu $4^{\circ}$ Cselama satu malam. Kemudian setelah satu malam dikeluarkan dan didiamkan pada suhu ruang selama \pm 15 menit. Selanjutnya sampel tepung tersebut dikeringkan menggunakan oven dengan suhu $60^{\circ} \mathrm{C}$ selama \pm 10 jam. Tepung yang sudah kering kemudian dihancurkan dengan blender. Setelah itu tepung diayak menggunakan ukuran 80 mesh hingga terbentuk tepung bengkuang modifikasi. Kemudian dilakukan analisis sifat fisik (derajat putih), sifat kimia (kadar air) dan sifat fisikokimia (daya serap air, kelarutan (sollubility), dan swelling power pada tepung bengkuang modifikasi yang dihasilkan.

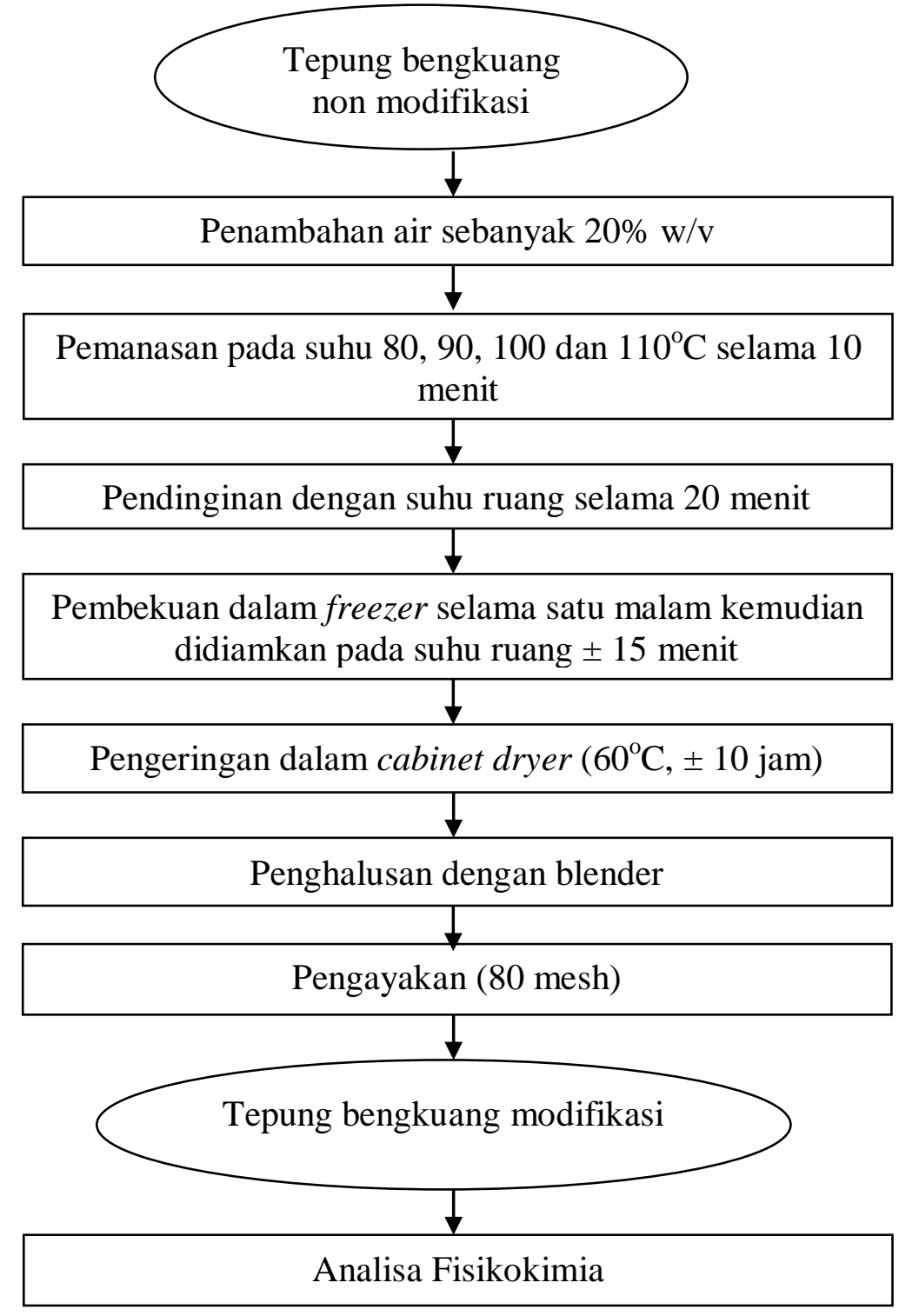

Gambar 2. Diagram Alir Pembuatan Tepung Bengkuang Modifikasi dengan Metode Pregelatinisasi 


\section{HASIL DAN PEMBAHASAN}

\section{Karakteristik Fisik Tepung Bengkuang Pre-gelatinisasi}

\section{Derajat Putih}

Hasil analisis derajat putih tepung bengkuang pre gelatinisasi dengan variasi suhu terhadap derajat putih dapat dilihat pada Tabel 1. Hasil data menunjukkan bahwa pregelatinisasi memberikan pengaruh yang sangat nyata terhadap derajat putih tepung bengkuang pre-gelatinisasi. Suhu $110{ }^{\circ} \mathrm{C}$ memberikan nilai derajat putih tepung bengkuang pre-gelatinisasi yang paling rendah dibandingkan perlakuan pregelatinisasi suhu $100{ }^{\circ} \mathrm{C}, 90{ }^{\circ} \mathrm{C}$, dan $80{ }^{\circ} \mathrm{C}$. Kondisi ini disebabkan semakin tinggi suhu pre-gelatinisasi akan semakin melarutkan komponen kimia dalam granula tepung seperti gula dan protein, sehingga memungkinkan gula dan protein untuk bereaksi menghasilkan pigmen berwarna coklat hasil reaksi maillard. Dari Tabel 1, tepung yang mempunyai derajat putih paling tinggi adalah tepung tanpa modifikasi dengan derajat putih sebesar $75,899 \%$. Sedangkan dari ke empat tepung bengkuang pregelatinisasi yang mempunyai derajat putih paling tinggi yaitu perlakuan suhu $80{ }^{\circ} \mathrm{C}$ sebesar 71,680\%. Dari keempat perlakuan tepung bengkuang pre-gelatinisasi mempunyai derajat putih yang cenderung menurun sering dengan kenaikan suhu pregelatinisasi.

Tabel 1 Pengaruh Variasi Suhu terhadap Derajat Putih Tepung Bengkuang Pre-gelatinisasi.

\begin{tabular}{cc}
\hline Suhu & Derajat putih $(\%)$ \\
\hline Kontrol & $75,899 \pm 0,076^{\mathrm{e}}$ \\
$80{ }^{\circ} \mathrm{C}$ & $71,680 \pm 0,077^{\mathrm{d}}$ \\
$90{ }^{\circ} \mathrm{C}$ & $70,448 \pm 0,380^{\mathrm{c}}$ \\
$100{ }^{\circ} \mathrm{C}$ & $68,926 \pm 0,059^{\mathrm{b}}$ \\
$110{ }^{\circ} \mathrm{C}$ & $66,733 \pm 0,114^{\mathrm{a}}$ \\
\hline Keterangan : angka yang diikuti huruf yang sama \\
& $\begin{array}{c}\text { menunjukan tidak berbeda nyata pada } \\
\text { taraf signifikansi } \alpha 0,05 .\end{array}$
\end{tabular}

Menurut Palupi, et al. (2011), penurunan nilai derajat putih disebabkan oleh proses pemanasan pada pre-gelatinisasi yang akan melarutkan beberapa komponen kimia dalam tepung dan sel pati seperti gula, amilosa, protein. Proses pengeringan kembali tepung yang tergelatinisasi memungkinkan senyawasenyawa terlarut tersebut, seperti gula perduksi dan protein bereaksi menghasilkan pigmen berwarna coklat, yang merupakan hasil dari reaksi maillard

\section{Karakteristik Kimia Tepung Bengkuang Pre-gelatinisasi}

\section{Kadar Air}

Hasil analisis kadar air tepung bengkuang pre-gelatinisasi dengan variasi suhu dapat dilihat pada Tabel 2. Tabel 2 menunjukkan bahwa variasi suhu berpengaruh nyata terhadap kadar air tepung bengkuang pre-gelatinisasi pada taraf signifikansi 0,05 . Tepung bengkuang non modikasi (kontrol) memiliki kadar air paling tinggi $(10,974 \%)$ dibandingkan tepung bengkuang pre-gelatinisasi yang menggunakan berbagai variasi suhu. Sedangkan kadar air terendah terdapat pada tepung bengkuang pre-gelatinisasi dengan suhu $80{ }^{\circ} \mathrm{C}(8,507 \%)$. Hasil ini sesuai teori bahwa kadar air maksimum yang diijinkan untuk tepung adalah 14-15\% (Fardiaz, 1989). Hasil penelitian menunjukkan bahwa kadar air tepung bengkuang yang mengalami proses pre-gelatinisasi berkisar antara $8,507 \%$ sampai $10,974 \%$.

Tabel 2 Pengaruh Variasi Suhu terhadap Kadar Air Tepung Bengkuang Pregelatinisasi.

\begin{tabular}{cc}
\hline Suhu & Kadar air $(\% \mathbf{w b})$ \\
\hline Kontrol & $10,974 \pm 0,307^{\mathrm{d}}$ \\
$80{ }^{\circ} \mathrm{C}$ & $8,507 \pm 0,116^{\mathrm{a}}$ \\
$90{ }^{\circ} \mathrm{C}$ & $9,197 \pm 0,174^{\mathrm{b}}$ \\
$100{ }^{\circ} \mathrm{C}$ & $9,291 \pm 0,371^{\mathrm{b}}$ \\
$110{ }^{\circ} \mathrm{C}$ & $10,002 \pm 0,202^{\mathrm{c}}$ \\
\hline Keterangan : angka yang diikuti huruf yang sama \\
\\
\\
\\
menunjukan tidak berbeda nyata pada \\
taraf signifikansi $\alpha 0,05$.
\end{tabular}

Perlakuan pre-gelatinisasi pada suhu yang berbeda $80{ }^{\circ} \mathrm{C}, 90{ }^{\circ} \mathrm{C}, 100{ }^{\circ} \mathrm{C}$ dan 110 ${ }^{\circ} \mathrm{C}$ memberikan pengaruh nyata pada kadar air tepung bengkuang. Perlakuan tersebut merupakan suhu dimana telah terjadi proses gelatinisasi dan pembengkakan granula. Menurut Winarno (2004), pati yang telah mengalami gelatinisasi dan mengalami pengeringan, mampu menyerap air kembali 
dalam jumlah yang besar. Sifat pati yang telah tergelatinisasi inilah yang dapat diaplikasikan pada berbagai produk pangan instan.

Semakin tinggi suhu yang digunakan maka kadar airnya pun semakin meningkat. Perlakuan pre-gelatinisasi pada tepung bengkuang memberikan peningkatan kadar air tepung secara nyata. Hal ini sesuai dengan penelitian pada tepung singkong pregelatinisasi oleh Palupi, et al. (2011). Rerata kadar air tepung singkong pre-gelatinisasi berkisar antara $11,93 \%$ sampai $14,71 \%$. Pemanasan yang dilakukan pada tepung bengkuang pre-gelatinisasi mengakibatkan granula pati menjadi membengkak dan menyebabkan lemahnya ikatan hidrogen dalam granula. Granula yang telah membengkak memiliki ukuran yang lebih besar. Sehingga dengan ukuran granula yang menjadi lebih besar, tepung akan menyerap air lebih banyak. Hal inilah yang menyebabkan meningkatnya nilai kadar air seiring dengan naiknya suhu pre-gelatinisasi.

\section{Karakteristik Fisikokimia Tepung Bengkuang Pre-gelatinisasi}

\section{Daya Serap Air}

Hasil analisis daya serap air tepung bengkuang pre-gelatinisasi dengan variasi suhu dapat dilihat pada Tabel 3. Hasil data menunjukkan bahwa variasi suhu pemanasan tepung bengkuang pre-gelatinisasi berpengaruh nyata terhadap daya serap air. Daya serap air tepung bengkuang tanpa modifikasi (kontrol) memiliki daya serap paling tinggi sebesar 3,437 g/g. Untuk tepung bengkuang pre-gelatinisasi mengalami peningkatan seiring kenaikan suhu. Daya serap air tepung bengkuang pre-gelatinisasi paling tinggi yaitu $2,514 \mathrm{~g} / \mathrm{g}$ ini mendekati daya serap tepung terigu $(2,5 \mathrm{~g} / \mathrm{g})$.

Pati pre-gelatinisasi adalah pati yang telah dikeringkan untuk merusak struktur granula. Pati pre-gelatinisasi mempunyai kemampuan menyerap air yang lebih tinggi daripada pati biasa dan mudah larut dalam air dingin (Rogol, 1986) serta cepat membentuk pasta dalam air dingin (Powell, 1967). Dimana semakin tinggi suhu pre-gelatinisasi maka daya serap airnya pun semakin meningkat. Semakin tinggi daya serap air pada tepung, maka kualitas tepung tersebut semakin baik karena tepung tersebut mampu menyerap air dengan baik.

Peningkatan daya serap air pada tepung bengkuang pre-gelatinisasi meningkat diduga karena banyaknya gugus hidroksil dalam molekul pati yang menyebabkan kemampuan menyerap airnya besar. Gugus hidroksil dalam molekul pati sangat banyak, sehingga kemampuan menyerap air juga sangat besar. (Suprapto, 2006). Panas yang diberikan pada perlakuan tepung pre-gelatinisasi menyebabkan ikatan hidrogen melemah sehingga air mudah masuk dan daya serap air menjadi tinggi. Meurut Asgar dan Musaddad (2006), tingginya daya serap air yang dihasilkan dengan perlakuan panas disebabkan air yang terserap dalam molekul menyebabkan pre-gelatinisasi yang meningkatkan daya serap air karena terputusnya ikatan hidrogen antarmolekul pati sehingga air lebih mudah masuk ke dalam molekul pati.

Tabel 3 Pengaruh variasi suhu terhadap sifat fiskokimia tepung bengkuang yang dimodifikasi

Suhu Daya serap air $(\mathrm{g} / \mathrm{g}) \quad$ Swelling power $\quad$ Solubility (\%)
$(\mathrm{g} / \mathrm{g})$

$\begin{array}{cccc}\text { Kontrol } & 3,438 \pm 0,107^{\mathrm{c}} & 5,966 \pm 0,118^{\mathrm{b}} & 12,749 \pm 0,834^{\mathrm{a}} \\ 80{ }^{\circ} \mathrm{C} & 2,308 \pm 0,003^{\mathrm{a}} & 3,412 \pm 0,498^{\mathrm{a}} & 43,832 \pm 0,692^{\mathrm{b}} \\ 90{ }^{\circ} \mathrm{C} & 2,378 \pm 0,054^{\mathrm{ab}} & 3,476 \pm 0,177^{\mathrm{a}} & 46,018 \pm 0,826^{\mathrm{c}} \\ 100{ }^{\circ} \mathrm{C} & 2,486 \pm 0,116^{\mathrm{b}} & 3,584 \pm 0,081^{\mathrm{a}} & 48,174 \pm 0,654^{\mathrm{d}} \\ 110^{\circ} \mathrm{C} & 2,514 \pm 0,088^{\mathrm{b}} & 3,662 \pm 0,089^{\mathrm{a}} & 48,581 \pm 0,223^{\mathrm{d}}\end{array}$

Keterangan : angka yang diikuti huruf yang sama menunjukan tidak berbeda nyata pada taraf signifikansi $\alpha 0,05$ 


\section{Swelling Power}

Hasil analisis swelling power tepung bengkuang pre-gelatinisasi dengan variasi suhu terhadap lama pemanasan dapat dilihat pada Tabel 3. Tepung bengkuang tanpa modifikasi memiliki swelling power lebih tinggi dibandingkan dengan tepung bengkuang pre-gelatinisasi Untuk tepung bengkuang tanpa modifikasi memiliki hasil sebesar 5,966\%. Hasil penelitian juga menunjukkan bahwa perbedaan suhu pregelatiniasi tidak menyebabkan perubahan secara signifikan nilai swelling power diantara sampel tepung yang dimodifikasi.

\section{Kelarutan (sollubility)}

Hasil analisis kelarutan (sollubility) tepung bengkuang pre-gelatinisasi dengan variasi suhu terhadap kelarutan dapat dilihat pada Tabel 3. Perbedaan variasi suhu pregelatinisasi yang digunakan menyebabkan peningkatan nilai kelarutan dari tepung yang dimodifikasi. Nilai kelarutan tepung bengkuang pre- gelatinisasi berkisar antara 43,832-48,581 \%. Nilai tertinggi kelarutan didapatkan pada tepung bengkuang pregelatinisasi yaitu 48,581 \%. Sedangkan tepung bengkuang tanpa modifikasi memiliki kelarutan $12,749 \%$. Nilai kelarutan yang tinggi mengindikasikan bahwa tepung bengkuang dengan perlakuan pregelatinisasi mudah larut dalam air. Pernyataan tersebut didukung oleh Rogol (1986), Pre-gelatinisasi adalah pati yang telah dikeringkan untuk merusak struktur granula. Pati pre-gelatinisasi mempunyai kemampuan menyerap air yang lebih tinggi daripada biasa dan mudah larut dalam air dingin serta cepat membentuk pasta dalam air dingin (Rogol 1986; Powell, 1967). Menurut Marchal et al., (1999) dan Hidayat et al., (2003), produk turunan pati memiliki daya serap air dan kelarutan dalam air yang lebih baik dibandingkan pati alami.

Semakin tinggi suhu pemanasan yang digunakan maka kelarutan tepung bengkuang pre-gelatinisasi pun semakin meningkat. Selain itu peningkatan kelarutan tepung pregelatinisasi diduga karena tepung telah terhidrolisa oleh panas dari suhu yang terus meningkat mengakibatkan ikatan hidrogen terputus sehingga fraksi pati terpecah menjadi rantai yang lebih pendek. dengan ukuran molekul yang lebih kecil tersebut maka mudah untuk larut dalam air. Pemanasan yang terus berlangsung akan menyebabkan granula pati pecah sehingga air yang terdapat dalam granula pati dan molekul pati yang larut air dengan mudah keluar dan masuk ke dalam sistem larutan (Baah, 2009).

\section{KESIMPULAN}

Berdasarkan penelitian yang telah dilakukan untuk mengetahui sifat fisikokimia tepung bengkuang termodifikasi secara pregelatinisasi dengan variasi suhu, dapat diambil kesimpulan bahwa peningkatan suhu pemanaan dalam pre-gelatinisasi akan menyebabkan peningkatan nilai kelarutan. Sehingga hasil penelitian ini mempunyai potensi untuk digunakan dalam bahan baku pembuatan produk instan yang menuntut nilai kelarutan yang tinggi pada produknya. Disamping, itu peningkatan suhu pregelatinisasi juga dapat meningkatkan nilai daya serap air dan kadar air, tetapi menurunkan derajat putih tepung bengkuang yang dimodifikasi. Sedangkan, nilai swelling power tidak berpengaruh signifikan seiring dengan kenaikan suhu pre-gelatinisasi

\section{DAFTAR PUSTAKA}

Asgar, A dan Musaddad., D. 2006. Optimalisasi Cara, Suhu dan Lama Blanching sebelum Pengeringan pada Wortel. Balai Penelitian Tanaman Sayuran Lembang. Bandung.

Baah, D. F. 2009. Characterization of Water Yam (Dioscorea atalata) for Existing and Potensial Food Products. Thesis. Faculty of Biosciences Kwame Nkrumah University, Nigeria.

Badan Pusat Statistik Kebumen (BPS). 2009. Produksi

http://kebumenkab.Bps.go.id/.27

desember 2013.

Chooi, O.H. 2008. Vegetables for Health and Healing. Utusan Publications and Distributors Sdn Phd. Kuala Lumpur. 
Fardiaz, S. 1989. Mikrobiologi Pangan. Jurusan Teknologi Pangan dan Gizi. Fateta IPB. Bogor.

Hidayat, B., Nurbani, K. dan Surfiana. 2009. Karakterisasi Tepung Ubi Kayu Modifikasi yang Diproses Menggunakan Metode Pragelatinisasi Parsial (Characterization Of Modified Cassava Flour Processed Through Partial Pregelatinisation Method). Politeknik Negeri Lampung Bandar Lampung. Jurnal Teknologi Industri dan Hasil Pertanian Volume 14, No 2, September 2009.

Marchal, L.M, Beeftink H.H, dan Tramper, J. 1999. Towards a Rational Design of Commercial Maltodekstrin. J. Trend in Food Science and Technology, 10(1): 345-355.

Palupi, H. T., Zainul A.,, dan Nugroho, M.. 2011. Pengaruh Pre Gelatinisasi Terhadap Karakteristik Tepung Singkong. Universitas Yudharta. Pasuruan. Vol. 1 No.1, Januari 2011.

Rogol, S. 1986. Starch modification : A view into the future. Cereal Foods World. 31 (12) : 869-874.

Suprapto, H. 2006. Pengaruh Perendaman Pisang Kepok (Musa acuminax balbisiana Calla) Dalam Larutan Garam Terhadap Mutu Tepung yang Dihasilkan. Jurnal Teknologi Pertanian 1(2): 74-80, Maret 2006.

Winarno, F.G. 2004. Kimia Pangan Dan Gizi. Jakarta: PT Gramedia Pustaka Utama. 